Available online on 20.12.2020 at http://jddtonline.info
OC 2011-18, publisher and licensee JDDT, This is an Open Access article which permits
unrestricted non-commercial use(CC By-NC), provided the original work is properly cited

Open $\odot$ Access

Research Article

\title{
Anti-Inflammatory Activity of Extract Mixture of Annona senegalensis Pers. and Piliostigma thonningii (Schum.)
}

\author{
Togbenou Komlatsè*, Idoh Kokou, Dosseh Kossivi, Kpatcha Tchazou and Agbonon Amégnona \\ Laboratoire de Physiologie et de Pharmacologie, Faculté des Sciences, Université de Lomé
}

\begin{abstract}
Introduction: Annona senegalensis Pers (Annonaceae) and Piliostigma thonningii (Schum.) (Leguminoseae) are two medicinal plants used, often in combination, in traditional Togolese medicine for the treatment of diseases with an inflammatory component.

Objective: The aim of this study is to evaluate the anti-inflammatory effect of the hydro-ethanolic extract (EHEM) of the combination of $A$. senegalensis and P. thonningii (1: $1, \mathrm{~m}: \mathrm{m})$.

Methods: The ovalbumin-induced allergic airway asthma model was used. Animals made asthmatic were treated with EHEM at doses of 250 and $500 \mathrm{mg} / \mathrm{kg}$. Inflammation markers including histamine, nitric oxide (NO), vascular leakage, leukocyte infiltration in the airways, and malondialdehyde (MDA), were measured.

Results: Compared to the SNT group, EHEM inhibits the infiltration of the airways by leukocytes $\left(850,00 \times 10^{3} \pm 50\right.$ cells $/ \mathrm{mL}$ vs $1830 \times 10^{3} \pm$ 53,85 cells / $\mathrm{mL}$ for ST500 mg / kg, P <0,05). It inhibited vascular permeability to Evans Blue $(10,40 \pm 0,270 \mu \mathrm{g} / \mathrm{mL}$ vs ST500, p<0,05). It inhibited histamine release $(13,95 \pm 0,937 \mu \mathrm{g} / \mathrm{mL}$ vs $32,78 \pm 1,044 \mu \mathrm{g} / \mathrm{mL}, \mathrm{p}<0,05)$ and NO production $(0,211 \pm 0,008 \mathrm{Mm}$ vs $0,315 \pm 0,022$ $\mu \mathrm{M}, \mathrm{p}<0,05)$. It finally inhibited MDA production $(14,66 \pm 0,533 \mathrm{nM} / \mathrm{mL}$ vs 9,014 $\pm 0,366 \mathrm{nM} / \mathrm{mL}$ and 7,149 $\pm 0,300 \mathrm{nM} / \mathrm{mL}, \mathrm{p}<0,05)$ in lung tissue.
\end{abstract}

Conclusion: Our results suggest that EHEM inhibits OVA-induced inflammation. These results justify the use of this combination of plants in traditional Togolese medicine.

Keywords: Inflammation, malondialdehyde, Annona senegalensis, Piliostigma thonningii.

Article Info: Received 13 Oct 2020; $\quad$ Review Completed 28 Nov 2020; $\quad$ Accepted 09 Dec 2020; Available online 20 Dec 2020

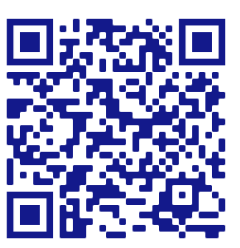

Cite this article as:

Togbenou K, Idoh K, Dosseh K, Kpatcha T. Agbonon A, Anti-Inflammatory Activity of Extract Mixture of Annona senegalensis Pers. and Piliostigma thonningii (Schum.), Journal of Drug Delivery and Therapeutics. 2020; 10(6-s):103-108 http://dx.doi.org/10.22270/jddt.v10i6-s.4605

Togbenou Komlatsè, Laboratoire de Physiologie et de Pharmacologie, Faculté des Sciences, Université de Lomé

\section{INTRODUCTION}

Chronic inflammation is one of the causes of a number of non-infectious diseases worldwide including asthma 1-2. Asthma, a chronic disorder of the airways, affects individuals of all ages in countries around the world. It is a health problem that can be serious and sometimes fatal. It is characterized by permanent inflammatory reactions of the airways and especially by bronchoconstriction that can worsen over time. The prevalence of asthma is increasing everywhere, especially in urban areas with high pollution, and particularly affects children. Asthma is a significant burden, not only in terms of health costs but also in terms of lost productivity and reduced participation in family life 3 . The treatment approach for inflammatory diseases is to inhibit the synthesis or action of mediators that stimulate inflammation with drugs, including non-steroidal antiinflammatory drugs (NSAIDs) and anticytokine therapies, such as antitumor necrosis factor (TNF- $\alpha$ ) 4 . Conventional medications recommended for the treatment of asthma often do not permanently treat the disease but relieve the attacks, leading to long-term treatments with significant side effects. These chronic treatments are expensive and could weaken the economic situation of patients who, in tropical countries and particularly in Africa, are very often turned to traditional medicine based on the use of plants $5-6$. Thus, the search for new natural molecules that are gentler, more available and above all have multiple actions, represents an undeniable hope in the resolution of these problems. Thus, in recent years, much research has been directed towards the valorization of traditional medicine, based on the use of medicinal plants, in order to verify the safety and efficacy of the plants used and to establish scientific rules for their use.

In Togo, Annona senegalensis Pers (Annonaceae) and Piliostigma thonningii (Schum.) (Leguminoseae) are used in 
traditional medicine for the treatment of diseases with an inflammatory component.A. senegalensis has been widely studied, on experimental in vivo and in vitro models of inflammatory and painful processes with total extracts, as well as phytochemical tests $7-8$. It has been reported that leaves of A. Senegalensis have anticonvulsant, depressant, and central anxiolytic properties attributable to flavonoids 9 . An anticonvulsant effect of kaurenoic acid isolated from root bark A. Senegalensis 10. A recent study had shown toxicity of the $\mathrm{N}$-hexane and chloroform fractions of leaf extract of $A$. Senegalensis on the immature stage of mosquito species such as Anopheles gambiae and Culex quinquefasciatus 11 .

Previous studies showed that $P$. thonningii, root bark fractions exhibited significant anti-inflammatory and analgesic activity against phenylquinone-induced contortions ${ }^{12}$. According to Rist $13, P$. thonningii root bark showed anti helminthic activity in veterinary medicine. According to Kerharo ${ }^{14}$, aqueous stem bark extract of of $P$. thonningii showed antibacterial activity against the bacterial strain Sarcina lutea While defibrated roots are used as a purgative, deworming agent and to alleviate dysentery, malaria, tuberculosis 15 .

In this study, we were interested in studying the antiinflammatory activity of the combination of these two plants.

\section{MATERIALS AND METHODS}

\section{Plant material and extraction}

Plant material is constituted of root bark A. senegalensis and stem bark $P$. thonningii. Both A. senegalensis and stem bark for $P$. thonningii were collected from Danyivi, southwest Togo in September 2017 in in. Botanical identification has been performed at the herbarium of the Botany Department of the Faculty of Sciences, University of Lomé where a voucher specimen of each plant has been deposited under the numbers TOGO15567 and TOGO15568 for A. senegalensi and P. thonningii respectively.

Fresh samples were washed with tape water and dried under air conditioning in the sunshine in the Laboratory of Physiology and Pharmacology of Natural Substances of the Université de Lomé. The dried samples were crushed using an electric mill. We made a combination of the two powders obtained $(1 / 1 ; \mathrm{m} / \mathrm{m})$ and macerated in an ethanol and water solvent $(80 / 20 ; \mathrm{v} / \mathrm{v})$ in the proportions of $10 \mathrm{~g}$ per $100 \mathrm{~mL}$ of solvent. The mixture is stirred occasionally at room temperature for 72 hours. The extract is filtered and dry evaporated at $40^{\circ} \mathrm{C}$ using a rotary evaporator (BÜCHI, Switzerland). The resulting hydroethanol extract of the mixture (EHEM) was stored in a refrigerator.

\section{Experimental animals}

Wistar strain rats of both sexes weighing between 140 and $160 \mathrm{~g}$ were used. Animals were reared in the animal house of the Laboratory of Physiology and Pharmacology of Natural Substances of the University of Lomé, at room temperature with a light/dark cycle of 12 hours with free access to food and water.

\section{Sensitization of rats to ovalbumin}

Rats were divided into four groups ( $n=5)$ : unsensitized or normal control group (NS), untreated sensitized group or control (SNT), and two groups treated with EHEM 250 and $500 \mathrm{mg} / \mathrm{kg}$ respectively (ST250 and ST500). Sensitization was performed by intraperitoneal injection of $10 \mathrm{mg} / \mathrm{kg}$ OVA (grade V; Sigma, St.Louis, MO, USA) mixed with $40 \mathrm{mg} / \mathrm{kg}$ aluminum hydroxide as adjuvant in normal saline $(0.9 \%)$ on days $0,3,7$ and 21 . Unsensitized animals were injected with aluminum hydroxide ( $40 \mathrm{mg} / \mathrm{kg}$ ) only. On days 24 to 27 , SNT and sensitized groups treated with EHEM, under mild ether anaesthesia were given intranasal instillations of $50 \mu \mathrm{l}$ of OVA (20\%) in normal saline. The NS group received normal saline as well.

Rats in the EHEM-treated groups received orally $10 \mathrm{ml} / \mathrm{kg}$ of 250 and $500 \mathrm{mg} / \mathrm{kg} 30$ minutes prior to OVA challenge, while the others were administered with normal saline. Rats were sacrificed on day 28. Bronchoalveolar lavage was performed by cannulating the trachea with a PE-240 polyethylene catheter (DI: $1.67 \mathrm{~mm}$, OD: $2.41 \mathrm{~mm}$ ) and infusing the lung with $5 \mathrm{ml}$ of $0.9 \%$ sterile saline. Bronchoalveolar fluid (BAL) was obtained by two tracheal cannulation aspirations and the BAL recovery rate was approximately $78-84 \% 16$.

\section{Leukocyte cell count in BAL}

The activity of EHEM on the infiltration of cells in the airways was evaluated, following the induction of allergy by OVA according to the method described by 16-17. Leukocyte cell count in the BAL was carried out using the Malassez cell mounted on an photomicroscope (OPTICA, Italy) connected to a microcomputer equipped with software (Optika Micro Image Analysis Software). This technique allows to count directly the leukocyte cells on the computer screen. results were expressed as the number of cells per $\mathrm{mL}$ of BAL volume recovered.

\section{Measurement of vascular permeability}

Plasma exudation is demonstrated by intravenous injection of Evans blue, which binds to plasma proteins. The effect of the ethanolic extract of the root of EHEM on OVA-induced vascular permeability in rats was evaluated according to the method described by Lilly et al and Agbonon et al 16-17. Four groups of rats were constituted as above. These rats were also sensitized and instilled with ovalbumin as described above. Twenty-four hours after the last intranasal instillation, animals were anaesthetized with $20 \%$ urethane (Sigma Chemical, St. Louis, MO, USA) at a dose of $1 \mathrm{~g} / \mathrm{kg}$. Evans blue (30 mg/ $\mathrm{kg}$ dissolved in $0.9 \% \mathrm{NaCl}$ solution) was administered to the rats via the tail vein. Five minutes later, the rats were sacrificed by urethane overdose. Bronchoalveolar fluid was collected as described above. The concentration of Evans blue was determined in the BAL by spectrophotometry using Genesys (Genesys, France) at a wavelength of $620 \mathrm{~nm}$ against the blank composed of a $0.9 \%$ $\mathrm{NaCl}$ solution. The concentration of Evans blue in the BAL was determined from the linear regression equation of the calibration curve generated from Evans blue dissolved in $0.9 \% \mathrm{NaCl}(0-10 \mu \mathrm{g} / \mathrm{mL})$.

The concentration of Evans blue expresses vascular permeability. The percentage inhibition of vascular permeability is calculated according to the following formula:

$\%$ inhibition $=[(($ SNTC $)-($ STC $)) /($ SNTC $)] \times 100$.

- SNTC: Concentration of Evans Blue in the BAL of untreated sensitized rats.

- STC: concentration of Evans blue in the BAL of sensitized and treated rats

\section{Determination of histamine in the BAL}

Rats were sensitized as before, but instillation with ovalbumin was performed from day 24 to day 28. The BAL was taken 30 minutes after the last instillation. Histamine determination assay was performed using the colorimetric method described by Yang et al. ${ }^{18}$. In short, to $0.5 \mathrm{~mL}$ of the 
BAL or standard histamine dihydrochloride were simultaneously added a $0.1 \mathrm{~mL}$ of $1 \%$ sulfanilic acid and 0.1 $\mathrm{mL}$ of a $5 \%$ sodium nitrite. The mixture was incubated for 10 minutes and afterwards $1.3 \mathrm{~mL}$ of the $5 \%$ sodium carbonate solution was added. Two (02) minutes later, $1 \mathrm{~mL}$ of $75^{\circ}$ ethanol was added to the mixture. The absorbance was read at $530 \mathrm{~nm}$ in the first 20 minutes using the UV-visible spectrophotometer. The concentration of histamine was determined from the calibration curve generated from regression equation established with histamine dihydrochloride (Sigma Chemical, St. Louis, MO, USA) dissolved in $0.9 \% \mathrm{NaCl}(0-50 \mu \mathrm{g} / \mathrm{mL})$.

\section{Determination of lipid peroxidation}

The concentration of malondialdehyde (MDA) was determined as an indicator of lipid peroxidation. Whole lung samples were dissected 24 hours after the last OVA instillation and washed immediately with ice saline to remove as much blood as possible. They were weighed and 2 $\mathrm{g}$ of tissue was homogenized in $5 \mathrm{ml}$ of a cold $\mathrm{KCl}$ solution (1.5\%). The homogenate was centrifuged at $3000 \mathrm{rpm}$ for 10 min. Subsequently, the MDA content in the supernatants was measured according to the method described by Agbonon and Gbeassor 19-20. Briefly, $200 \mu \mathrm{l}$ of supernatant was exposed to $0.6 \mathrm{ml}$ of phosphoric acid (1\%) and $1 \mathrm{ml}$ of thiobarbituric acid (1\%) and the mixture was heated at $100^{\circ} \mathrm{C}$ for $50 \mathrm{~min}$. At the end of the incubation period, the mixture was cooled in ice for $10 \mathrm{~min}$ and $2 \mathrm{ml}$ of 1-butanol was added and the mixture was centrifuged as described above. After centrifugation, the supernatant was removed and the absorbance was read at $535 \mathrm{~nm}$ using a UV-visible recording spectrophotometer (Genesys 10S UV-Vis Spectrophotometer, France). 1,1,3,3-tetramethoxypropane (MDA) was used as standard to obtain the standard curve $(0$ $\left.-60 \mathrm{nM} ; \mathrm{y}=0.03860 \mathrm{x}+0.04205 ; \mathrm{r}^{2}=0.998\right)$.

\section{Measurement of NO}

Pulmonary NO production was determined spectrophotometrically by assaying BAL liquid for nitrite using Griess reagent (1\% sulfanilic acid, $0.1 \% \quad \mathrm{~N}-1$ naphthylenediamine dihydrochloride, $2.5 \%$ phosphoric acid). In each test tube were introduced in the order $100 \mu \mathrm{L}$ of BAL and $100 \mu \mathrm{L}$ of Griess reagent. After homogenization, the absorbance of each tube was read at $570 \mathrm{~nm}$ after 10 minutes incubation against the blank. The concentration of the NO solution was measured spectrophotometrically against the blank. The nitrite concentration was determined using sodium nitrite as standard 21.

\section{Statistical analyses}

Results are expressed as mean \pm standard error of the mean (mean \pm SEM). Comparisons between the means of different groups were performed using one-way analysis of variance (ANOVA) followed by a post-hoc Tukey test. Results were considered significant at $\mathrm{P}<0.05$. All statistical analyses were performed using GraphPad Prism 5.00 (GraphPad Software Inc., CA, USA).

\section{RESULTS}

Effect of EHEM on the infiltration of leukocytes in the respiratory tract

Exposure of rats to OVA caused a significant increase in the number of leukocytes in the BAL of the sensitized control group (NST) compared to the unsensitized control group (NS) $\left(3190 \times 10^{3} \pm 100.50\right.$ cells / mL vs. $850.00 \times 10^{3} \pm 50$ cells / $\mathrm{mL}, \mathrm{P}<0.001$ ). In contrast, treatment of rats in the (ST250 and ST500) groups with EHEM prior to OVA exposure resulted in a significant decrease $(\mathrm{P}<0.001)$ in the number of leukocyte cells compared to the sensitized control (SNT) group $(850,00 \times 103 \pm 50$ cells / $\mathrm{mL}$ for the control group vs. $2170 \times 103 \pm 134.70$ cells / $\mathrm{mL}$ and $1830 \times 103 \pm 53.85$ cells / $\mathrm{mL}$ for ST250 and ST500 mg/kg extract respectively, P < 0.001) (Figure 1).

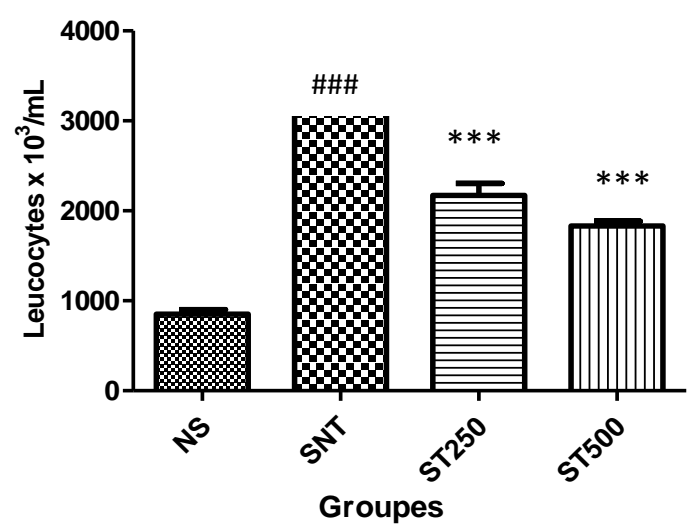

Figure 1: Total number of leukocytes in the BAL

Values are expressed as mean \pm ESM $(n=5) ;$ NS = unsensitized group; SNT = group sensitized and instilled with OVA; ST250, ST500: groups sensitized and treated with EHEM at 250 and 500 $\mathrm{mg} / \mathrm{kg}$; \# \# \#P $<0.001$ compared to NS; ${ }^{* * * P}<0.001$ : significant differences from SNT (one-factor ANOVA followed by Tukey's multiple comparison test).

\section{Effect of EHEM on vascular permeability}

Intranasal instillation with OVA in OVA-sensitized control rats (SNT) increased vascular permeability compared to non-sensitized rats (NS). Values for the concentration of Evans Blue in BAL are $7.077 \pm 0.238 \mu \mathrm{g} / \mathrm{mL}$ in the unsensitized control rats and $10.40 \pm 0.270 \mu \mathrm{g} / \mathrm{mL}$ in the sensitized control rats. Treatment of ST250 and ST500 groups prior to each instillation resulted in significant $(\mathrm{P}<$ 0.001 ) inhibition of vascular permeability in the airway compared to the untreated sensitized group. The concentrations of Evans Blue in the BAL are 3.506 \pm 0.175 $\mu \mathrm{g} / \mathrm{mL}$ and $1.683 \pm 0.272 \mu \mathrm{g} / \mathrm{mL}$ for ST250 and ST500 respectively (Figure 2).

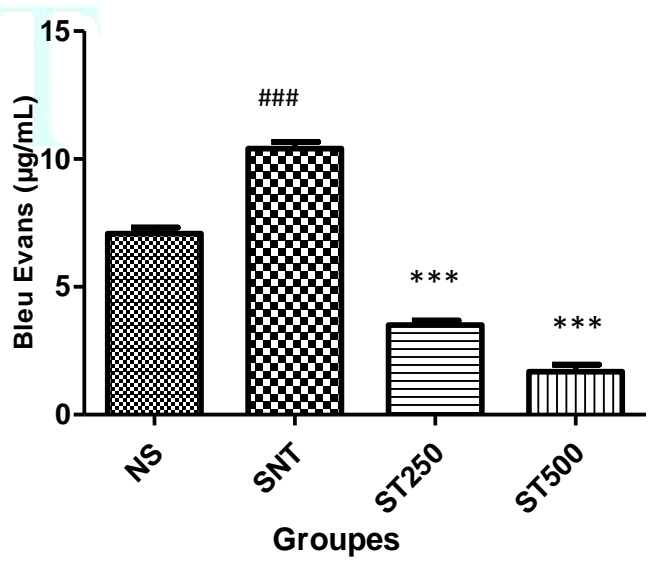

Figure 2: Effect of EHEM on Vascular Permeability

Values are expressed as mean \pm ESM ( $n=5)$; NS: non-sensitized group; SNT: sensitized group treated with $0.9 \% \mathrm{NaCl}$; ST250, ST500: groups sensitized and treated with EHEM at 250 and $500 \mathrm{mg} / \mathrm{kg}$; \# $\# \# \mathrm{P}<0.001$ : significant difference from NS; ${ }^{* * *} \mathrm{P}<0.001$ : significant difference from SNT (single-factor ANOVA followed by Tukey's multiple comparison test).

\section{Effect of EHEM on histamine concentration in the BAL}

The histamine assay showed that exposure of OVAsensitized rats to OVA caused a significant $(P<0.001)$ increase in the concentration of histamine in the BAL 
compared to the non-sensitized control group (32.78 \pm $1.044 \mu \mathrm{g} / \mathrm{mL}$ vs. $19.11 \pm 1.220 \mu \mathrm{g} / \mathrm{mL}$ ). On the other hand, we find a significant reduction $(\mathrm{P}<0.001)$ in histamine concentration only in the ST500 group's BAL compared to the SNT group $(13.95 \pm 0.937 \mu \mathrm{g} / \mathrm{mL}$ vs. $32.78 \pm 1.044$ $\mu \mathrm{g} / \mathrm{mL}$ ) (Figure 3).

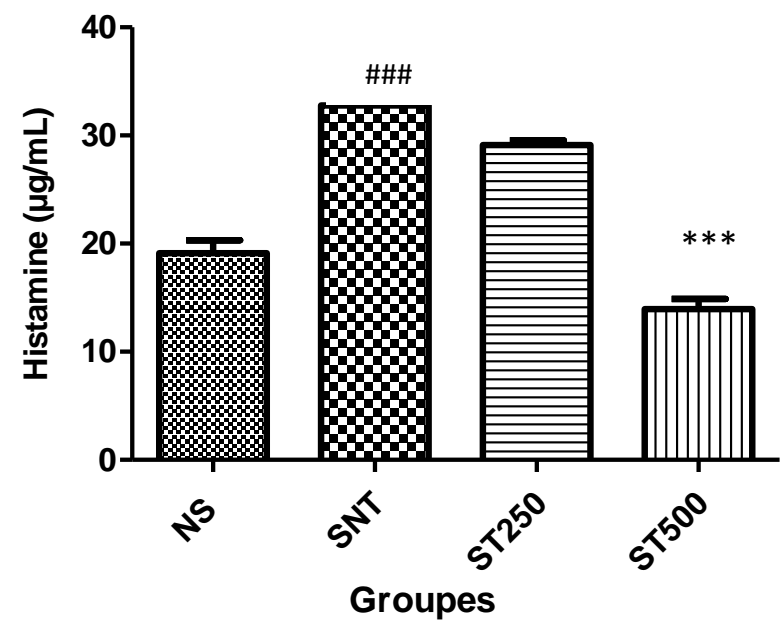

Figure 3: Effect of EHEM on Histamine Concentration

Values are expressed as mean \pm ESM $(n=5)$; NS: non-sensitized group; SNT: sensitized group treated with $0.9 \% \mathrm{NaCl}$; ST250, ST500: sensitized groups treated with EHEM at 250 and $500 \mathrm{mg} / \mathrm{kg}$; \# \# P 0.001: significant difference from NS; ${ }^{* *} \mathrm{P}<0.001$ : significant difference from SNT (single-factor ANOVA followed by Tukey's multiple comparison test).

\section{Effect of EHEM on Lipid Peroxidation in Lung Tissue}

Estimation of lipid peroxidation by estimating MDA levels showed a significant increase $(\mathrm{P}<0.001)$ in the concentration of MDA in the lung tissue of untreated sensitized rats (SNT) compared to unsensitized rats (NS) i.e. $(14.66 \pm 0.533 \mathrm{nM}$ vs. $9.273 \pm 0.337 \mathrm{nM})$. Treatment of ST250 and ST500 rats with EHEM prior to each instillation significantly reduced MDA formation in these lots compared to the SNT group $(9.014 \pm 0.366 \mathrm{nM}$ and $7.149 \pm 0.300 \mathrm{nM}$ vs. $14.66 \pm 0.533 \mathrm{nM}$ ) (Figure 4 )

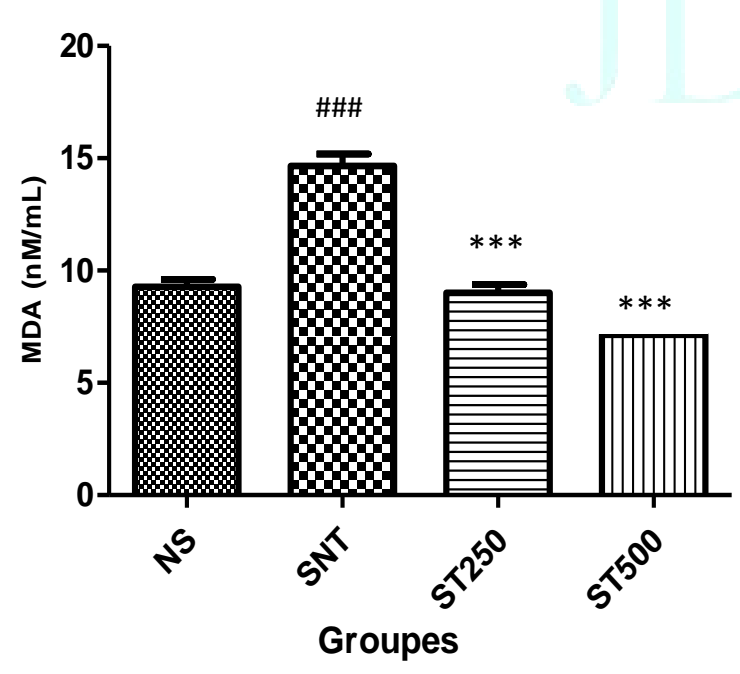

Figure 4: Effect of EHEM on Lipid Peroxidation in Lung Tissues

Values are expressed as mean \pm ESM, $\mathrm{n}=5$; NS: non-sensitized group; SNT: sensitized group treated with $0.9 \% \mathrm{NaCl}$; ST250, ST500: groups sensitized and treated with EHEM at 250 and $500 \mathrm{mg} / \mathrm{kg}$; \# \# \#P $<0.001$ : significant difference from NS; ${ }^{* * *} \mathrm{P}<0.001$ : significant difference from SNT (one-factor ANOVA followed by Tukey's multiple comparison test).

\section{Effect of EHEM on the production of nitric oxide (NO)}

The NO concentration in BAL is $0.181 \pm 0.014 \mu \mathrm{M}$ in NS rats. This value increased significantly $(\mathrm{p}<0.001)$ in OVAsensitized and OVA-induced (SNT) rats $(0.315 \pm 0.022 \mu \mathrm{M})$. In rats sensitized and treated with EHEM, there was a significant decrease $(p<0.01)$ in NO concentration only in the ST500 lot compared to untreated sensitized rats (SNT), i.e. $(0.211 \pm 0.008 \mathrm{Mm}$ vs $0.315 \pm 0.022 \mu \mathrm{M}$ ) (Figure 5).

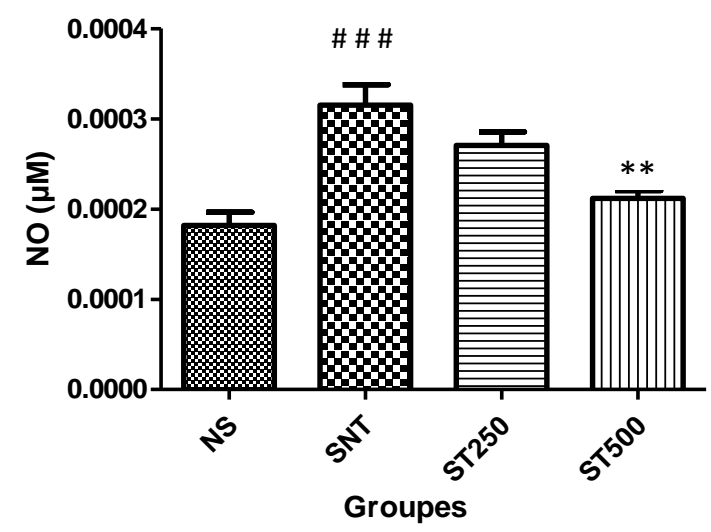

Figure 5: Effect of EHEM on NO

SNT: group sensitized, OVA-induced and treated with $0.9 \% \mathrm{NaCl}$; ST250, ST500: groups sensitized, OVA-induced and treated with EHEM at 250 and $500 \mathrm{mg} / \mathrm{kg}$; \#\# $<$ P 0.001: significant difference from NS; ${ }^{* *} \mathrm{P}<0.01$ : significant difference from SNT (one-factor ANOVA followed by Tukey's multiple comparison test).

\section{DISCUSSION}

The objective of this study was to assess the effect of EHEM from the combination of A. senegalensis and P. thonningii, on some parameters of chronic inflammation, with a view to scientific validation of its traditional use. EHEM inhibited dose dependent leukocyte infiltration into the respiratory tract, inhibited the permeability of Evans Blue to vascularized vessels, significantly reduced histamine production in rats treated with this extract. EHEM also showed a significant dose-dependent reduction in MDA and NO levels in rats treated with this extract.

We used an animal model of allergic asthma in which OVA is used as an allergen. Ovalbumin-induced asthma results from chronic airway inflammation associated with infiltration of leukocytes such as macrophages, lymphocytes, mastocytes, neutrophils and eosinophils into the lumen of the bronchial tract 22-23. Depletion of leukocytes in the airways in ovalbumin-sensitized rats treated with EHEM inhibits the asthmatic response 24 . Results from, this present study suggest that EHEM inhibited leukocytes passage across rats' airways wall. These leukocytes, once they arrive at the inflammation area, release pro-inflammatory substances that lead to vasodilation, increased vascular permeability and vascular leakage $25-26$.

Our results revealed an increased total leukocyte cells count in OVA-sensitized rats, characterizing asthmatic inflammation. Moreover, the number of total leukocyte cells count was much higher in the OVA-sensitized rats as compared to non-sensitized group due to the increase in other cell types such as lymphocytes and basophils. These cells amplify the immune response and thus participate in the development of inflammation with destruction of the bronchial epithelium leading to remodeling of lung tissue 27.

However, administration of EHEM in OVA-sensitized rats significantly reduced pulmonary infiltration by these inflammatory cells. This suggests that treatment with EHEM 
might reduce the inflammatory state by bringing white blood cell count back to normal and by decreasing the recruitment of white blood cells in the lungs.

Our results also showed that EHEM inhibits the permeability of Evans blue to vascular tissue. Indeed, during the inflammatory process, vascular permeability is exacerbated. This permeability leads to plasma exudation, which contributes to enriching the extravascular environment with factors designed to maintain and amplify the inflammatory response 28 . This study shows that EHEM inhibited vascular permeability, indicating that it can modulate the amplitude of the inflammatory response.

Histamine is a pro-inflammatory substance released by leukocyte cells. It is an amine released during mast cell degranulation. The significant decrease $(\mathrm{P}<0.001)$ of its concentration in the bronchoalveolar fluid of instilled and treated rats shows that the extract inhibited the release of this mediator or prevented the passage of mast cells into the respiratory tract. Since histamine is a vasodilator, it therefore increases vascular permeability. Results of histamine measurement in BAL suggest the physiological mechanism involved in anti-inflammatory effect of EHEM on OVA-induced chronic in rats. This would likely be due to secondary metabolites, mainly tannins, on cAMP and intracellular calcium-mediated histamine release ${ }^{29}$. Or $A$. senegalensis and $P$. thonningii contain tannins ${ }^{30-31}$.

In individuals with inflammatory diseases, a permanent state of oxidative stress has been demonstrated and is characterized by an imbalance between the biochemical processes involved in the production of reactive oxygen species (ROS) and those responsible for their control and elimination 32-33. During the inflammatory process, neutrophils and macrophages recruited at the inflammatory site release oxygenated and nitrated free radicals indicating the presence of oxidative stress ${ }^{34}$.

This imbalance between the defense and free radical production systems leads to biochemical damage at the level of the body's cells, including damage to the integrity of the cell membrane through the induction of lipid peroxidation 35-36. Thus, analysis of free radicals in biological membranes was performed using malondialdehyde (MDA), one of the degradation products of cyclic endoperoxides generated during lipid oxidation, determination assay. Malondialdehyde is an early indicator of foreign aggression and is often used as a biomarker of oxidative stress ${ }^{37-38}$.

In this present study, MDA level increased in untreated but OVA-sensitized group, indicating the occurrence of damage to the cell membranes. These results are consistent with those reported by Agbonon et al. 16 and Missebukpo et al. 39 . Pretreatment of rats with EHEM significantly prevented the increase in MDA content. Our results, suggest that the extract inhibits lipid peroxidation and preserves the integrity of the lungs of the asthmatic rats. Furthermore, these results confirm the effect of the extract on vascular permeability.

It has been reported that the occurrence of oxidative stress is due to the overproduction of nitric oxide (NO). Higher intracellular contents of NO react with other free radicals including the superoxide anion (02-) to form the peroxynitrite anion (ONOO-), a powerful oxidant 40. Activation of leukocyte cells in inflammatory process induce overproduction of NO under the action of inducible nitric oxide synthase (iNOS) ${ }^{40}$. INOS-induced overproduction of NO is mostly associated with highly detrimental proinflammatory effects ${ }^{41-42}$. In airway inflammation ailments, $\mathrm{NO}$ is produced by a variety of cells in the respiratory tract, including not only inflammatory cells but also epithelial cells 43. Nitric oxide therefore plays a crucial role in the pathogenesis of airway inflammation in allergic asthma 43 . In this study, EHEM inhibited NO production in treated rats. This suggests that the extract inhibited overproduction of NO and MDA and therefore inhibited oxidative stress while avoiding its adverse effects.

\section{CONCLUSION}

Ultimately, this study showed that EHEM inhibits: airway infiltration by leukocytes, vascular permeability, histamine release and NO production in bronchoalveolar fluid (BAL) and then MDA production in lung tissue. This suggests that EHEM would inhibit OVA-induced inflammation. What are then the molecules resulting from this combination and which are responsible for this anti-inflammatory activity? Our future perspectives will attempt to answer this question.

\section{REFERENCES}

[1] Komakech R, Kim Y, Matsabisa GM, Kang Y. Anti-inflammatory and Analgesic Potential of Tamarindus indica Linn. (Fabaceae): A Narrative Review. Integrative Medicine Research. 1 sept 2019; 8(3):181-6.

[2] Steven S, Frenis K, Oelze M, Kalinovic S, Kuntic M, Bayo Jimenez MT, et al. Vascular Inflammation and Oxidative Stress: Major Triggers for Cardiovascular Disease. Oxid Med Cell Longev [Internet]. 23 juin 2019 [Cited on October 20, 2020];2019. Available from:
from https://www.ncbi.nlm.nih.gov/pmc/articles/PMC6612399/

[3] Holt S, Masoli M, Beasley R. The use of the self-management plan system of care in adult asthma. Prim Care Respir J. mars 2004;13(1):19-27.

[4] Regional Committee for Africa 50. Promoting the role of traditional medicine in health systems: A strategy for the African Region. 2000 [Cited on October 20, 2020]; Available from: https://apps.who.int/iris/handle/10665/95467

[5] Mamedov N, Craker L. Medicinal Plants Used for the Treatment of Bronchial Asthma in Russia and Central Asia. Journal of Herbs, Spices \& Medicinal Plants. 11 juill 2001; 8:91-117.

[6] Bhat SS, Hegde KS, Chandrashekhar S, Rao SN, Manikkoth S. Preclinical screening of Phyllanthus Amarus Ethanolic Extract for its Analgesic and Antimicrobial Activity. Pharmacognosy Res. 2015; 7(4):378-84.

[7] Okhale SE, Akpan E, Fatokun OT, Esievo KB, Kunle OF. Annona senegalensis Persoon (Annonaceae): A review of its Ethnomedicinal Uses, Biological Activities and Phytocompounds. Journal of Pharmacognosy and Phytochemistry. 2016;5(2):211.

[8] Okoli CO, Onyeto CA, Akpa BP, Ezike AC, Akah PA, Okoye TC. Neuropharmacological Evaluation of Annona senegalensis leaves. African Journal of Biotechnology. 2010; 9(49):84358444.

[9] Okoye TC, Akah PA, Omeje EO, Okoye FB, Nworu CS. Anticonvulsant effect of kaurenoic acid isolated from the root bark of Annona senegalensis. Pharmacology Biochemistry and Behavior. 2013; 109:38-43.

[10] Lame Y, Nukenine EN, Pierre DYS, Elijah AE, Esimone CO. Laboratory Evaluations of the Fractions Efficacy of Annona senegalensis (Annonaceae) Leaf Extract on Immature Stage Development of Malarial and Filarial Mosquito Vectors. Journal of arthropod-borne diseases. 2015; 9(2):226.

[11] Orwa C, Mutua A, Kindt R, Jamnadass R, Simons A. Agroforestree Database: A tree Reference and Selection Guide Version 4.0. 2009. Url: http://www worldagroforestry org/af/treedb/(Accessed on 15 February, 2011). 2015.

[12] Rist G. Le développement-4 édition: Histoire d'une Croyance Occidentale. 4 édition revue et Augmentée. Presses de Sciences Po; 2015.

[13] Kerharo J, Adam J-G. La Pharmacopée sénégalaise Traditionnelle: Plantes Médicinales et Toxiques. 1974;

[14] DIABATE MDM. Etude de la Phytochimie et des Activités Biologiques d'une Recette Traditionnelle Utilisée dans le Traitement de l'hypertrophie Bénigne de la Prostate au Mali. 2006; 
[15] Agbonon A, Aklikokou K, Eklu-Gadegbeku K, Akpagana K, Gbeassor M. Effect of Ethanolic Extract of Pluchea ovalis root in Asthma Model of Wistar Rat. Boletin Latinoamericano y del caribe de plantas medicinales y Aromaticas. 2005; 4(3):52-59.

[16] Lilly CM, Chapman RW, Sehring SJ, Mauser PJ, Egan RW, Drazen JM. Effects of Interleukin 5-induced Pulmonary Eosinophilia on Airway Reactivity in the guinea pig. American Journal of Physiology-Lung Cellular and Molecular Physiology. 1996; 270(3):L368-L375.

[17] Yang XX, Powell WS, Hojo M, Martin JG. Hyperpnea-induced Bronchoconstriction is Dependent on Tachykinin-induced Cysteinyl Leukotriene Synthesis. Journal of Applied Physiology. 1997; 82(2):538-544.

[18] Agbonon A, Gbeassor M. Hepatoprotective Effect of Lonchocarpus sericeus leaves in CCl4-induced Liver Damage. Journal of herbs, spices \& medicinal plants. 2009; 15(2):216226.

[19] Dosseh K, Kpatcha T, Adjrah Y, Idoh K, Agbonon A, Gbéassor M. Antiinflammatory Effects of Byrsocarpus coccineus shum and thonn (Connaraceae) root. World J Pharmaceut Res. 2014;3:3585-3598.

[20] Fermor B, Weinberg JB, Pisetsky DS, Misukonis MA, Banes AJ, Guilak F. The Effects of Static and Intermittent Compression on Nitric Oxide Production in Articular Cartilage Explants. Journal of Orthopaedic Research. 2001; 19(4):729-737.

[21] Roh S-S, Kim S-H, Lee Y-C, Seo Y-B. Effects of radix adenophorae and cyclosporine A on an OVA-induced murine model of asthma by suppressing to $\mathrm{T}$ cells activity, eosinophilia, and bronchial hyperresponsiveness. Mediators of inflammation. 2008; 2008.

[22] Suralkar AA, Kasture SB. Inhibitory Effect of Abrus Precatorious Extract on Bronchial Hyper-reactivity Induced by Ovalbumin in Experimental Animals. Int J Pharm Pharm Sci. 2013; 5(1):403404.

[23] Schuster M, Tschernig T, Krug N, Pabst R. Lymphocytes Migrate from the Blood into the Bronchoalveolar Lavage and Lung Parenchyma in the Asthma Model of the Brown Norway rat. American Journal of Respiratory And Critical Care Medicine. 2000; 161(2):558-566.

[24] Awortwe C, Sackeyfio AC, Osei-Safo D, Bugyei KA, AsieduGyekye IJ. Dual Effect of Taraxacum officinale Leaves: Anticholinergic and Inhibitory Effect on Inflammatory cells in Ovalbumin-sensitized guinea-pigs. African Journal of Pharmacy and Pharmacology. 2011; 5(23):2613-2619.

[25] Lindner I, Meier C, Url A, Unger H, Grassauer A, PrieschlGrassauer E, et al. Beta-escin has Potent Anti-allergic Efficacy and Reduces Allergic Airway Inflammation. BMC immunology. 2010; 11(1):24.

[26] Holgate ST. Pathogenesis of asthma. Clinical \& Experimental Allergy. 2008; 38(6):872-897.

[27] Cochet M, Pannetier C, Regnault A, Darche S, Leclerc C, Kourilsky P. Molecular Detection and in vivo Analysis of the Specific T cell Response to a Protein Antigen. European Journal of Immunology. 1992; 22(10):2639-2647.

[28] Kim DY, Yang WM. Panax ginseng Ameliorates Airway Inflammation in an Ovalbumin-sensitized Mouse Allergic Asthma Model. Journal of Ethnopharmacology. 2011; 136(1):230-235.

[29] Egharevba HO, Kunle FO. Preliminary Phytochemical and Proximate Analysis of the Leaves of Piliostigma thonningii (Schumach.) Milne-Redhead. Ethnobotanical Leaflets. 2010; 2010(5):2.
[30] Johnson TO, Olatunde A, Nwachukwu L. Phytochemical Composition of Annona senegalensis Leaf and its Antioxidant Activity during Trypanosoma brucei brucei induced Oxidative Stress in Mice. Journal of Pharmacy \& Bioresources. 2017; 14(2):219-227.

[31] Powers SK, Smuder AJ, Kavazis AN, Hudson MB. Experimental Guidelines for Studies Designed to Investigate the Impact of Antioxidant Supplementation on Exercise Performance. International Journal of Sport Nutrition and Exercise Metabolism. 2010; 20(1):2-14.

[32] Bloomer RJ, Fisher-Wellman KH. Blood oxidative Stress Biomarkers: Influence of Sex, Exercise Training Status, and Dietary intake. Gender Medicine. 2008; 5(3):218-228.

[33] Jung H-J, Nam JH, Choi J, Lee K-T, Park H-J. Antiinflammatory Effects of Chiisanoside and Chiisanogenin Obtained from the Leaves of Acanthopanax Chiisanensis in the Carrageenan-and Freund's complete Adjuvant-induced rats. Journal of Ethnopharmacology. 2005; 97(2):359-367.

[34] Terziev L, Dancheva V, Shopova V, Stavreva G. Antioxidant Effect of MnTE-2-PyP on lung in Asthma Mice Model. The Scientific World Journal. 2012; 2012.

[35] Al-Afaleg NO, Al-Senaidy A, El-Ansary A. Oxidative Stress and Antioxidant Status in Saudi Asthmatic Patients. Clinical Biochemistry. 2011; 44(8-9):612-617.

[36] Ladhar-Chaabouni R, Gargouri R, Hamza Chaffai A. Effect of Cadmium on Some Biomarkers in the Clam Ruditapes Decussatus: Metallothionein Quantification Using two Techniques. International Journal of Environment and Pollution. 2007; 30(3-4):593-605.

[37] Giguère A, Couillard Y, Campbell PG, Perceval O, Hare L, PinelAlloul B, et al. Steady-state Distribution of Metals among Metallothionein and Other Cytosolic Ligands and Links to Cytotoxicity in Bivalves living along a Polymetallic Gradient. Aquatic Toxicology. 2003; 64(2):185-200.

[38] Missebukpo A, Metowogo K, Diallo A, Lawson-Evi P, EkluGadegbeku K, Aklikokou KA, et al. Antioxidant Effects of Lxora coccinea Linn. in a Rat Model of Ovalbumin-induced Asthma. African Journal of Pharmacy and Pharmacology. 2013; 7(42):2794-2800.

[39] Zhu H, Li YR. Oxidative Stress and Redox Signaling Mechanisms of Inflammatory Bowel Disease: Updated Experimental and Clinical Evidence. Experimental Biology and Medicine. 2012; 237(5):474-480.

[40] Napolitano DR, Mineo JR, De Souza MA, De Paula JE, Espindola LS, Espindola FS. Down-modulation of Nitric Oxide Production in Murine Macrophages Treated with Crude Plant Extracts from the Brazilian Cerrado. Journal of Ethnopharmacology. 2005; 99(1):37-41.

[41] Laskin DL, Fakhrzadeh L, Laskin JD. Nitric Oxide and Peroxynitrite in Ozone-induced Lung Injury. In: Biological Reactive Intermediates VI. Springer; 2001. p. 183-190.

[42] Van der Vliet A, Eiserich JP, Cross CE. Nitric oxide: A Proinflammatory Mediator in Lung Disease? Respiratory Research. $2000 ; 1(2): 1$.

[43] Shin I-S, Lee M-Y, Ha H, Jeon W-Y, Seo C-S, Shin H-K. Dianthus Superbus Fructus Suppresses Airway Inflammation by Downregulating of Inducible Nitric Oxide Synthase in an Ovalbumin-induced Murine Model of Asthma. J Inflamm (Lond). 30 oct $2012 ; 9(1): 41$. 